\title{
Local budgets of municipal districts of rural type
}

\author{
E. B. Dvoryadkina ${ }^{1 凶}$, O. A. Belikova ${ }^{2}$ \\ ${ }^{1}$ Ural State University of Economics, Ekaterinburg, Russia \\ ${ }^{2}$ Ural State Mining University, Ekaterinburg, Russia \\ $\bowtie$ E-mail: elena.dvoryadkina@yandex.ru
}

Abstract. The topicality of this article is due to firstly, the need to study local budgets as a factor in the economic growth of rural municipal districts and as a component of the economic basis of local self-government; secondly, the presence of problems in the formation and execution of local budgets of rural municipalities due to their inherent features. In the budget system structure, based on the criteria of the municipal structure, there are distinguished various types of local budgets, among which the largest group is the local budgets of rural municipalities, combining local budgets of municipalities and local budgets of rural settlements. Local budgets of rural municipalities are components of a regional financial system. The purpose of the study is to assess trends and development factors of local budgets of rural municipalities against the background of a set of local budgets. Research methods: allocation and justification of the features of rural municipalities in the financial aspect, affecting the formation and execution of their local budgets; a method of structural analysis of indicators of local budgets of municipal districts and local budgets of rural settlements in the context of such components as budget revenues, budget expenditures, budget deficits, which allows us to assess the extent of their presence in the corresponding aggregate of local budgets. The results of the study and their scientific novelty: confirmation of the hypothesis on the development trends of local budgets of rural municipalities against the background of local budgets of other types of municipalities: there are trends in the reduction of income and expenditures of local budgets of municipalities and rural settlements in the general indicators of local budgets, against the background of the trend strengthening the imbalance of local budgets of rural municipalities.

Keywords: rural municipality, local budget, rural settlement, municipal district.

For citation: Dvoryadkina E. B., Belikova O. A. Local budgets of municipal districts of rural type // Agrarian Bulletin of the Urals. 2019. No. 12 (191). Pp. 84-88. DOI: ...

Paper submitted: 07.06.2019.

\section{Introduction}

The problems of the formation and execution of local budgets, on the one hand, as a factor of the economic growth of a municipality, on the other hand, as a component of the economic basis of local self-government, are invariably relevant. In modern conditions that are characterized by the emergence of new trends in economic development associated with new industrialization, digitalization of the economy, local budgets continue to retain their importance to ensure the solution of issues of local importance by local governments. Among the types of municipalities that exist in the Russian Federation, we especially single out municipal areas and rural settlements, which are combined in such a complex concept as rural municipal districts [20, p. 85].

The dynamics of the number of rural municipalities in the Russian Federation is presented in table 1.

In general, there is a negative trend in the number of municipalities - over the period under review, the number of municipalities decreased by 1962 units, and this reduction was most active due to rural settlements, the number of which decreased by 1819 units. This trend is due to the processes of transformation of the municipal structure: the transformation (unification) and the abolition of municipalities. At the same time, there was done work on the delimitation of powers between local government at different levels and state authori- ties, as well as on securing the appropriate sources of income for them.

The current version of the Federal Law "About the General Principles of the Organization of Local Self-Government in the Russian Federation" refers to the jurisdiction of municipalities 40 issues of local importance, and to the conduct of rural settlements - only 13 .

\section{Methods}

Modern scientists study various problems and issues of the formation and execution of local budgets of various types of municipalities. L. I. Pronina [11; 12] presents problems of autonomy of regions and municipalities, including financial aspects, as well as directions for the effective implementation of the federalism principles and subsidiarity in inter-budget relations at the level of regions and municipalities in articles. V. V. Levina [8; 9] analyzes features of managing the balance of local budgets in conditions of financial instability. Setting priority tasks for managing budgetary resources, including strengthen the revenue potential of regional and local budgets is devoted study of D. A. Artemenko, M. R. Pinskaya and E. V. Porollo [19]. T. V. Sumskoi [13, 14] characterizes actual problems and features of the formation of local budgets, as well as directions for their use.

From the standpoint of the local government problems, including its territorial organization, there are the works 
The dynamics of the number of municipalities of the rural type in the Russian Federation

\begin{tabular}{|l|c|c|c|}
\hline \multirow{2}{*}{} & \multicolumn{3}{|c|}{ Rural-type municipalities } \\
\cline { 2 - 4 } & \multirow{2}{*}{ Total } & \multicolumn{2}{|c|}{ Including } \\
\cline { 2 - 4 } & 23907 & Municipal areas & 19591 \\
\hline on 1.01 .2010 & 23304 & 1829 & 18996 \\
\hline on 1.01 .2011 & 23118 & 1824 & 18833 \\
\hline on1.01.2012 & 23001 & 1821 & 18722 \\
\hline on 1.01 .2013 & 22777 & 1815 & 18525 \\
\hline on 1.01 .2014 & 22923 & 1823 & 18564 \\
\hline on 1.01 .2015 & 22406 & 1788 & 18177 \\
\hline on 1.01 .2016 & 22327 & 1784 & 18101 \\
\hline on 1.01 .2017 & 21945 & 1758 & 17772 \\
\hline on 1.01.2018 & -1962 & -71 & -1819 \\
\hline Change, units & & & \\
\hline
\end{tabular}

Note: the table is compiled by [15; 16].

of A. N. Adukova [1], R. V. Babuna [2], E. M. Buchwald, N. V. Voroshilov [3; 4]. The financial and budgetary aspects of the sustainable development of rural territories were investigated by T. V. Yurchenko [17; 18], L. P. Voronina [5]. Analysis of publications on the topic of our study allows us to conclude that insufficient attention is paid to the study of trends and development factors of local budgets of rural municipalities in the system of local budgets.

The purpose of the study is to assess trends and development factors of local budgets of rural municipalities against the background of a set of local budgets.

\section{Results}

Municipal districts of the rural type in the financial aspect are characterized by the following features.

Firstly, due to the fact that rural municipalities are usually peripheral territories, the level of concentration of financial resources in them is low.

Secondly, the tax potential of municipalities of a rural type is less developed compared to municipalities of an industrial type, especially the largest and large cities, since the bulk of large taxpayers - industrial enterprises, as well as organizations of other types of economic activity are concentrated on the territory of cities of this type, and the main number of payers of tax on personal income. The economic space of rural municipalities is less saturated with objects that form the tax potential.

Thirdly, rural municipalities have less developed opportunities for generating non-tax revenues of local budgets, as forms of using municipal property are implemented more passively in comparison with other types of municipal districts.

Fourthly, rural-type municipalities are characterized by a low degree of financial independence, which is manifested in the presence of higher values of subsidized indicators in the structure of their local budget revenues compared with other types of municipalities.

Fifthly, rural municipalities, unfortunately, are not areas of banking development, since there are few large economic agents on their territory that are demanding banking services, credit resources, etc.

Sixthly, rural settlements as representatives of rural municipalities are actively using the financial mechanism of selftaxation of citizens, in contrast to large municipalities. The use of self-taxation in small municipalities contributes to a more effective solution to the issues of development and arrangement of specific territories.

Let us imagine the position of budgets of rural municipalities in the structures of regional financial and budget subsystems using statistical indicators (table 2).

\section{Discussion and Conclusion}

The situation of local budgets of rural municipalities against the background of local budgets is characterized by the following circumstances.

Firstly, the share of local rural budgets in the total amount of local budgets in the reporting period is relatively stable, there are no significant structural changes, however, a trend should be noted for a decrease in the share of local budgets of rural settlements (in 6 federal districts) and a trend for a decrease in the specific weight of local budgets of municipal districts (in 5 federal districts). There is an increase in the share of local budgets of other types of municipalities.

Secondly, the budgets of rural municipalities continue to be unbalanced during the period under review, expenses consistently exceed revenues, which significantly complicates the solution of local issues by local authorities of municipalities and rural settlements, and the imbalance of local budgets is increasing, as evidenced by the corresponding deficit indicators

Thirdly, as rural municipalities, on the whole, have limited possibilities for forming a financial base that ensures the independence of local self-government, it is precisely in rural municipalities that such a financial instrument is used more actively than other types of municipalities: self-taxation of citizens. According to the Ministry of Finance of the Russian Federation, self-taxation of citizens was introduced in 2017 in the territories of 1,687 municipalities, which is $7.6 \%$ of the total number of municipalities (in 2016, 35 regions, 1,567 municipalities). According to the data of the constituent entities of the Russian Federation, almost the entire volume (99.2\%) of self-taxation proceeds in 2017 came from settlements, out of the total amount of self-taxation funds $86.6 \%$ went to the budgets of rural settlements and $12.6 \%$ to the budgets of urban settlements. Federal Law of December 5, 2017 No. 389-FL "About Amending Articles 25.1 and 56 of the Federal Law", "About General Principles of Local Self-Government in the Russian Federation", provides for the possibility of introduc- 
Local budgets of municipal districts and rural settlements in 2010-2017, million rubles

\begin{tabular}{|c|c|c|c|c|c|c|}
\hline \multirow[b]{2}{*}{ Indexes } & \multicolumn{3}{|c|}{2010 year } & \multicolumn{3}{|c|}{2017 year } \\
\hline & Income & Expenses & $\begin{array}{l}\text { Deficit (-), } \\
\text { surplus (+) }\end{array}$ & Income & Expenses & $\begin{array}{l}\text { Deficit (-), } \\
\text { surplus (+) }\end{array}$ \\
\hline \multicolumn{7}{|c|}{ Central Federal District } \\
\hline Local budgets, total & 418647 & 436534 & -17887 & 703013 & 729663 & -26650 \\
\hline \multicolumn{7}{|l|}{ Including: } \\
\hline Municipal budget & 186676 & 192905 & -6229 & 305395 & 314282 & -8887 \\
\hline Specific weight, $\%$ & 44.6 & 44.2 & 34.8 & 43.4 & 43.1 & 33.3 \\
\hline Rural budgets & 21970 & 22751 & -781 & 38715 & 41721 & -3006 \\
\hline Specific weight, \% & 5.2 & 5.2 & 4.4 & 5.5 & 5.7 & 11.3 \\
\hline \multicolumn{7}{|c|}{ Northwestern Federal District } \\
\hline Local budgets, total & 185974 & 194272 & -8298 & 263827 & 274142 & -10315 \\
\hline \multicolumn{7}{|l|}{ Including: } \\
\hline Municipal budget & 81731 & 84627 & -2896 & 107534 & 109176 & -1642 \\
\hline Specific weight, \% & 44.0 & 43.6 & 34.9 & 40.8 & 39.8 & 15.9 \\
\hline Rural budgets & 10202 & 10375 & -173 & 12070 & 13159 & -1089 \\
\hline Specific weight\% & 5.5 & 5.3 & 2.1 & 4.6 & 4.8 & 10.6 \\
\hline \multicolumn{7}{|c|}{ Southern Federal District } \\
\hline Local budgets, total & 193323 & 205697 & -12374 & 336548 & 348099 & -11551 \\
\hline \multicolumn{7}{|l|}{ Including: } \\
\hline Municipal budget & 75473 & 79222 & -3749 & 140045 & 142689 & -2644 \\
\hline Specific weight, \% & 39.0 & 38.5 & 30.3 & 41.6 & 41.0 & 22.9 \\
\hline Rural budgets & 14097 & 15298 & -1201 & 19516 & 21252 & -1736 \\
\hline Specific weight, \% & 7.3 & 7.4 & 9.7 & 5.8 & 6.1 & 15.0 \\
\hline \multicolumn{7}{|c|}{ North Caucasus Federal District } \\
\hline Local budgets, total & 94069 & 96855 & -2786 & 154620 & 166777 & -12157 \\
\hline \multicolumn{7}{|l|}{ Including: } \\
\hline Municipal budget & 50679 & 50895 & -216 & 88697 & 98165 & -9468 \\
\hline Specific weight, \% & 53.9 & 52.5 & 7.8 & 57.4 & 58.9 & 77.9 \\
\hline Rural budgets & 7342 & 7425 & -83 & 8770 & 8844 & -74 \\
\hline Specific weight, \% & 7.8 & 7.7 & 3.0 & 5.7 & 5.3 & 0.6 \\
\hline \multicolumn{7}{|c|}{ Volga Federal District } \\
\hline Local budgets, total & 386936 & 399447 & -12511 & 586406 & 604605 & -18199 \\
\hline \multicolumn{7}{|l|}{ Including: } \\
\hline Municipal budget & 170149 & 172542 & -2393 & 243996 & 248582 & -4586 \\
\hline Specific weight, \% & 44.0 & 43.2 & 19.1 & 41.6 & 41.1 & 25.2 \\
\hline Rural budgets & 22439 & 21826 & 613 & 28294 & 29259 & -965 \\
\hline Specific weight, \% & 5.8 & 5.5 & - & 4.8 & 4.8 & 5.3 \\
\hline \multicolumn{7}{|c|}{ Ural Federal District } \\
\hline Local budgets, total & 293587 & 302256 & -8669 & 500737 & 515767 & -15030 \\
\hline \multicolumn{7}{|l|}{ Including: } \\
\hline Municipal budget & 84933 & 85915 & -982 & 139778 & 144230 & -4452 \\
\hline Specific weight, \% & 28.9 & 28.4 & 11.3 & 27.9 & 28.0 & 29.6 \\
\hline Rural budgets & 7757 & 7863 & -106 & 13546 & 13871 & -325 \\
\hline Specific weight, \% & 2.6 & 2.6 & 1.2 & 2.7 & 2.7 & 2.2 \\
\hline \multicolumn{7}{|c|}{ Siberian Federal District } \\
\hline Local budgets, total & 367220 & 375786 & -8566 & 535260 & 554665 & -19405 \\
\hline \multicolumn{7}{|l|}{ Including: } \\
\hline Municipal budget & 142417 & 143441 & -1024 & 216681 & 219882 & -3201 \\
\hline Specific weight, \% & 38.8 & 38.2 & 12.0 & 40.5 & 39.6 & 16.5 \\
\hline Rural budgets & 17146 & 17466 & -320 & 24769 & 25661 & -892 \\
\hline Specific weight, $\%$ & 4.7 & 4.6 & 3.7 & 4.6 & 4.6 & 4.6 \\
\hline & & Far Ec & n Federal Di & & & \\
\hline Local budgets, total & 186148 & 193815 & -7667 & 307091 & 317344 & -10253 \\
\hline Including: & & & & & & \\
\hline Municipal budget & 80596 & 83890 & -3294 & 117571 & 118889 & -1318 \\
\hline Specific weight\% & 43.3 & 43.3 & 43.0 & 38.3 & 37.5 & 12.9 \\
\hline Rural budgets & 10331 & 10447 & -146 & 15153 & 15561 & -408 \\
\hline Specific weight, \% & 5.5 & 5.4 & 1.9 & 4.9 & 4.9 & 4.0 \\
\hline
\end{tabular}

Note: the table is compiled by: Formation of local self-government in the Russian Federation on January 1, 2018: Bulletin of the Federal State Statistics Service. Moscow, 2018; The formation of local government in the Russian Federation on January 1, 2010: Bulletin of the Federal State Statistics Service.

Moscow., 2010 // Official website of the Federal State Statistics Service http://www.gks.ru. 
ing self-taxation not only in the entire municipality, but also in the territory of a separate population center paragraph on the gathering of citizens [7].

Fourthly, in the context of a constant deficit of local budgets, rural municipalities do not have the ability to form development budgets. Inter-budget transfers make a significant share of their income. The budgetary provision of rural municipalities is lower in comparison with other municipalities.

In the medium term, financial factors related to the sphere of inter-budgetary relations will be determined by the solution of tasks in such areas as:

- assistance in balancing the budgets of entities and local budgets;

- reduction of federal regulation of the tax base of the regions;
- improving the efficiency of budget expenditures and budget consolidation;

- creating predictable, transparent and comfortable conditions for the provision of financial assistance.

In general, since the local budgets of rural municipalities are also subject to a significant influence of regional factors, the functioning of mechanisms for solving such problems, such as: improvement of intergovernmental relations; development of the revenue base of local budgets; expansion of the program-targeted approach in the formation of the regional budget. In addition, current trends in the development of relations in the field of public finance impose new requirements on the composition and quality of information on the financial activities of municipalities, as well as on the transparency of information on the results of their activities.

\section{References}

1. Adukova A. N. Sovershenstvovaniye mestnogo samoupravleniya kak bazovoye usloviye sel'skogo razvitiya [Improving local government as a basic condition for rural development] // Ekonomika sel'skogo khozyaystva Rossii. 2016. No. 12. Pp. 8085. (In Russian.)

2. Babun R. V. Territorial'naya organizatsiya mestnogo samoupravleniya: sistemnyy podkhod [Territorial organization of local government: a systematic approach] // Munitsipal'noe pravo. 2016. No. 1. Pp. 2-7. (In Russian.)

3. Bukhval'd E. M., Voroshilov N. V. Aktual'nye voprosy razvitiya municipal'nykh obrazovaniy i reformirovaniya instituta mestnogo samoupravleniya [Actual issues of the development of municipalities and the reform of the institution of local selfgovernment] // Economic and social changes: facts, trends, forecast. 2018. T. 11. No. 1. Pp. 132-147. (In Russian.)

4. Bukhval'd E. M., Pechenskaya M. A. Vozmozhnosti mestnykh byudzhetov pri realizatsii munitsipal'nykh strategiy razvitiya [Opportunities of local budgets in the implementation of municipal development strategies] // Problems of territory's development. 2017. No. 4 (90). Pp. 37-50. (In Russian.)

5. Voronina L. P. Finansovo-ekonomicheskoe obespechenie polnomochiy sel'skikh poseleniy [Financial and economic support for the authority of rural settlements] // Munitsipalitet: ekonomika i upravleniye. 2013. No. 1. Pp. 74-82. (In Russian.)

6. Dvoryadkina E. B., Belikova O. A., Aragilyan I. V. Byudzhety sel'skikh territoriy v strukture regional'nykh finansovobyudzhetnykh podsistem [Budgets of rural territories in the structure of regional financial and budgetary subsystems] // Agrarian Bulletin of the Urals. 2015. No. 3. Pp. 48-53. (In Russian.)

7. Informatsiya o rezul'tatakh provedeniya monitoringa ispolneniya mestnyh byudzhetov i mezhbyudzhetnykh otnosheniy v sub"ektakh Rossiyskoy Federatsii na regional'nom i munitsipal'nom urovnyakh za 2017 god [Information on the results of monitoring the implementation of local budgets and intergovernmental relations in the constituent entities of the Russian Federation at the regional and municipal levels for 2017] [e-resource] // Ofitsial'nyy sayt Ministerstva finansov Rossiyskoy Federatsii. URL: https://www.minfin.ru/ru/perfomance/regions/monitoring_results/Monitoring_local/results/ (appeal date: 15.04.2019). (In Russian.)

8. Levina V. V. Osobennosti upravleniya sbalansirovannost'yu mestnykh byudzhetov v usloviyakh finansovoy nestabil'nosti [Features of managing the balance of local budgets in the context of financial instability] // The manager. 2015. No. 3. Pp. 1217. (In Russian.)

9. Levina V. V. Mestnyye finansy v novoy situatsii [Local finance in a new situation] // EKO. 2018. No. 10. Pp. 153-170. (In Russian.)

10. Ob utverzhdenii Strategii ustoychivogo razvitiya sel'skikh territoriy Rossiyskoy Federatsii na period do 2030 goda: Rasporyazheniye Pravitel'stva Rossiyskoy Federatsii ot 02.02.2015 g. No. 151-r [About the approval of the Strategy for the Sustainable Development of Rural Territories of the Russian Federation for the period until 2030: order of the government of the Russian Federation] // Konsul’tant-Plyus: Spravochnaya pravovaya sistema (In Russian.)

11. Pronina L. I. Regiony i munitsipalitety: problemy, reformirovaniye, finansirovaniye v sovremennykh usloviyakh Rossii [Regions and municipalities: problems, reform, financing in modern conditions of Russia] // Ekonomika i upravleniye: problemy, resheniya. 2017. T. 1. No. 8. Pp. 14-25. (In Russian.)

12. Pronina L. I. Munitsipalitety: nalogi, mezhbyudzhetnye transferty iz federal'nogo byudzheta V 2018-2020 gg. [Municipalities: taxes, intergovernmental transfers from the federal budget in 2018-2020] // Ekonomika i upravleniye: problemy, resheniya. 2017. T. 2. No. 12. Pp. 10-16. (In Russian.)

13. Sumskaya T. V. Osnovnyye problemy formirovaniya mestnykh byudzhetov v Rossiyskoy Federatsii [The main problems of formation of local budgets in the Russian Federation] // Pravovestnik. 2018. No. 2 (4). Pp. 44-48. (In Russian.)

14. Sumskaya T. V. Osobennosti formirovaniya i napravleniy ispol'zovaniya mestnykh byudzhetov v Rossiyskoy Federatsii [Features of the formation and use of local budgets in the Russian Federation] // Interekspo Geo-Sibir'. 2018. T. 1. No. 3. Pp. 100-109. (In Russian.) 
15. Formirovaniye mestnogo samoupravleniya v Rossiyskoy Federatsii na 1 yanvarya 2010 g.: Byulleten' Federal'noy sluzhby gosudarstvennoy statistiki. [Formation of local self-government in the Russian Federation as of January 1, 2010: Bulletin of the Federal State Statistics Service] [e-resource] // Ofitsial'nyy sayt Federal'noe sluzhby gosudarstvennoe statistiki. URL: URL: https://www.gks.ru/compendium/document/13263 (appeal date: 15.04.2019). (In Russian.)

16. Formirovaniye mestnogo samoupravleniya v Rossiyskoy Federatsii na 1 yanvarya 2018 g.: Byulleten' Federal'noy sluzhby gosudarstvennoy statistiki. [Formation of local self-government in the Russian Federation as of January 1, 2018: Bulletin of the Federal State Statistics] [e-resource] // Ofitsial'nyy sayt Federal'noe sluzhby gosudarstvennoe statistiki. URL: https://www.gks. ru/compendium/document/13263. (appeal date: 15.04.2019). (In Russian.)

17. Yurchenko T. V. Optimizatsiya finansovykh potokov kak faktor povysheniya ustoychivosti razvitiya sel'skikh territoriy [Optimization of financial flows as a factor in increasing the sustainability of rural development] // Rossiyskiy elektronnyy nauchnyy zhurnal. 2015. No. 4 (18). Pp. 144-154. (In Russian.)

18. Yurchenko T. V. Problema povysheniya ustoychivosti byudzhetov sel'skih territoriy [The problem of increasing the sustainability of the budgets of rural territories] // Sotsial'no-ekonomicheskaya rol' deneg v obshchestve: Materialy XII Mezhdunarodnoy nauchno-prakticheskoy konferentsii. Saint Petersburg, 2016. Pp. 301-306. (In Russian.)

19. Artemenko D. A., Pinskaya M. R., Porollo E. V. Instruments of the enhancement of the formation and allocation of regional and local budget [Instruments of the enhancement of the formation and allocation of regional and local budget] // Global economy in the XXI century: dialectics of confrontation and solidarity. London, 2018. Pp. 365-377.

20. Dvoryadkina E. B., Belousova E. A. Municipal districts in economic space of a region: constructive and destructive trends // Izvestiya Uralskogo gosudarstvennogo ekonomicheskogo universiteta. 2018. T. 19. No. 5. Pp. 84-106.

\section{Authors' information:}

Elena B. Dvoryadkina ${ }^{1}$, doctor of economic sciences, professor, vice rector for research, professor of department of regional, municipal economics and management, ORCID 0000-0001-5163-0334, AuthorID 308967; +7 (343) 221-27-48, elena.dvoryadkina@yandex.ru

Olga A. Belikova ${ }^{2}$, candidate of economic sciences, associate professor of the department of finance and credit, ORCID 0000-0002-9902-0444, AuthorID 750595; +7 (343) 283-05-21,nicolay007@mail.ru

${ }^{1}$ Ural State University of Economics, Ekaterinburg, Russia

${ }^{2}$ Ural State Mining University, Ekaterinburg, Russia 